Fortunately, however, this earthquake was prevented from being excessivcly destructive by the unusual slowness of the oscillations. The period of the principal movements appears to have been not far short of two seconds. For a rough estimate of the greatest velocity and acceleration we may treat the 4.3 centimetres movement as simply harmonic, and we find for the greatest velocity 6.8 centimetres per second, and for the greatest acceleration 2 I centimetres per second per second, or $\frac{1}{4}$ ? of $g$. If the amplitude of motion which was recorded here had occurred in conjunction with the more usual period of three-quarters of a second or so, the destruction would have been immense. The carthquake appears to have been felt over an area of about 20,000 square miles.

Mr. Sekiya writes:- "We are going to exhibit your seismograph in the Exhibition in London, to be held next May. I am surc we will get a first prize medal!" Whether Mr. Sekiya and the Tokio University authorities get their medal or not they should at least excite the admiration of readers of N $\triangle T U R F$ for the zeal and success with which they are pursuing the study of seismology.

University College, I undee

\title{
EARLY MATURITY OF LIVE STOCK
}

$T^{\mathrm{r}}$

$E$ subject of the "Early Maturity of Live Stock" is, no doubt, bucolical in some of its aspects; but, like many other agricultural questions, it is of great national importance, and is closely related to scicntific investigations of much interest. 'The age at which the live stock of the farm becomes sufficicntly mature has been considerably reduced during the past hundred years, both by improved methods of feeding, and still more by the altered habit of the breeds of animals-that is, by their earlicr maturity induced by the modern systcm of breeding. Most persons are awarc that the "improved shorthorns" were the artificial creation of two eminent breeders, the Messrs. Colling; that the "improved longhorn" cattlc and Lcicestcr sheep were the result of skilful selection and intcr-breeding by Mr. Bakewcll; and that Mr. Ellman conducted similar "improvements" on the Southdown breed of sheep. All thesc operations upon the earlier types of animals were initiated in the last century, and they were so successful, from a practical point of view, that both bulls and rams were raised in price from about $5 \%$. to $20 \%$ respectively to 1000 guineas for single animals of high character and esteemed pedigree in the flocks and herds of Colling and I3akewell.

Other brocders have applied the same arts, and especially the principle of selection, to some of the other breeds, and their ubject has becn earlier maturity. It is obvious that a farmer must adopt that course of feeding which is most cconomical, and as a certain amount of food is consumed every day by an animal for respitatory and other vital functions, it is evicient that the sooner it is fit for the butcher the loss total amotnt of fond it will consume wastefully. In the manufacture of meat the food rcquired by an animal for its own purposes may be regarded as waste; so that the importance of saving time in the process of fattening is evident. It is said, indeed, that one-half of the food given to an animal under ordinary circumstances is required for the support of life, and, if that calculation be correct, then a slow-maturing ox, or sheep, at four years old will have consumed twicc as much food to produce the same weight as an animal of improved breed at two ycars old. The period of youth is the period of growth, when the muscles, bones, and other parts arc in process of formation, and when the waste of food is necessarily less than it must be at a later period of life. For the sakc of economy all animals should be fattened and finished when young, and therefore the question of "early maturity" involves an inquiry into the period of life when the domesticated animals attain their full maturity and development.

Prof. Low, in his "Domesticated Animals," and $\mathrm{Mr}$. Youatt, the famous spccialist, state that the ox and sheep in a state of nature attained complete maturity at from four to five years old, their permanent teeth being then complete. This was the stage they had reached about a hundred years ago, when the country was covered with woods and wastes, before the great inclosures, and before the turnip becamc a field-crop. Stall-feeding had not becn introduced at that period, and summer beef, fed on the marshes and natural pastures, was the only beef, and was, for winter use, invariably salted. The scanty provender of those days retarded maturity and postponed the usual period of producing young by more than a year, compared with the present time. At this stage the great brceders took up their severial subjects with results so markcd, and, it may be added, so remarkable, that within a few generations the complete maturity both of sheep and cattle-except in regard to the permanent teeth-had been reached in thrce years instead of four. The epoch of three-ycar-old mutton had now been reached, and some persons perhaps may still remcmber that luxury of their youth; and, if so, they must be aware that it exists no longer. In our own expcrience we must confess to have found old multon rather tough, and, while admitting that "the grapes arc sour," we see no reason why old beef and mutton should be superior to old geese and other poultry, or old game. But, however this may be, the perseverance of modern agriculturists and the competition of Australia and America in our meat markets, have led to still further reductions in the ages at which animals are slaughtered.

The action of our leading agricultural societies attests that some very recent movements have taken place for the purpose of stimulating breeders and feeders in the saving of still more food and time by early maturity. There must be a limit in these matters. Sheep and cattle of massive build are less ephemeral than some creatures, and a certain amount of time must always be required by them before their periods of complete development and of reproduction of the species can be reached. In 1875, however, the Smithfield Club offered prizes for lambs, having previously confined their favours to sheep onc year older at Jeast. There is no rulc without exception, and one particular breed of sheep has been incited by arts and wiles, and, for the sake of "Christmas lamb," to produce its offspring in November, and to do so permancntly. Usually lambs appear in spring; the "cattle show" is held in December, and lambs at nine or ten months old are now cxpected to exhibit thensclves as shecp of great weight. They have responded to the call in the most wonderful manner; they have not only out numbered the other "sheep" in the show, but they secured the champion prize for the best sheep last year as well as the ycar before, and their weights have cqualled those of the old sheep of other days, i.e. 16 and 18 Smithfield stone $(8 \mathrm{lbs})$, or $3 \frac{1}{2}$ lbs. of multon per week from birtl! !

Cattle under two years old werc first admitted in 1880 , and their achievements, too, have been astounding. Farly maturity, in short, has reached a new and unexpected stage. It has certainly been hastened, and cattle are now as fit for slaughter at two years old as they were formerly at twice that age. It is worthy of note, from a scientific point of view, that the period of complcte dentition, as it occurs in a state of nature, has not been much, if at all, altered. It is true that $M$. Regnault, the French scientist, discovered a bull at a cattlc fair in France in 1846 with all the permanent teeth fully developed. He was led to investigate the effects of careful breeding and fecding in occasioning that precocious development which has been already described, and this, he says, "cannot be confined to any particular organs. If every one has not equally participated in it, at least they are all more or less affected by it. Above all, the digestive system, the part 
called on to play an important part in producing such an aptitude for early devclopment, since all must essentially result from the nature and action of alimentation, must be one of the first to undergo modifications."

We do not question this conclusion, but the teeth and horns seem at present to have been slightly influenced by the "improvements" we have been considering. It is true that the art of breeding can greatly modify the horns; it can, in fact, obliterate them in horned cattle, and produce them in the hornless breeds, but this is quite apart from early maturity, which does not necessarily modify to any great extent, or with any certainty, either the horns or the teeth. Occasional examples of a very early development of the teeth, such as M. Regnault describes, do sometimes occur, but they are so rare as to be regarded as abnormal, and the rule, with the improved as with the older breeds of cattle, is that they produce two permanent teeth at two years old, and two others each year till they are five years old, when they are, as farmers say, "fullmouthed." It is not improbable, however, that the not very unfrequent appearance of the first permanent teeth at less than two years old, as well as the irregular dentition of highly-bred pigs, are manifestations that further and future changes may still be anticipated. Among many useful agricultural pamphlets that have been issued from the office of The Field, it is stated that one will appear shortly on "The Early Maturity of Live Stock."

H. E.

\section{THE BORNEO COAL-FIELDS}

HAVING recently visited some of the coal-fields in the Island of Borneo, it may be interesting to your readers to know the result. The subject was one of special interest to me, and its investigation was one of the principal objects I proposed to myself in my travels in the East. Just before leaving Australia I had published in the Proceedings of the Linnean Society of New South Wales a complete history of the known coal flora of Australia, and a review of its geological position. The relation of the Australian to the Indian coal flora is well known. It seemed hardly possible that in Borneo, where such extensive coal-formations exist, but that some connecting link would be found between Australia and India.

The subject is very little known. The late Mr. Motley had the management of the Labuan Mines. His are the only writings on the age of the Borneo coal which are known to me. What he wrote is quoted by Mr. Wallace in his work on "Australasia." He regarded the beds as Tertiary, and the fossils as of species of plants and marine mollusca now living on the coast. He speaks of cocoanuts and the.peculiar winged seeds of Dipterocarpus (so common in Borneo) being common also in the coal at Labuan. He thought that the beds evidently originated in the most recent times from masses of drift-wood brought down by the rivers and stranded on the coast, in the way the traveller sees so often repeated on the Borneo coast at the present day. He also stated that the Labuan coal was not, properly speaking, coal, but more Jike driftwood partially bituminised.

Mr. Motley subsequently was killed by the natives at Banjermassim. It is now six or seven years since the mines at Labuan have been worked. I am not sure that he had the same impressions about the South Borneo coal as of the Labuan beds, but I think J am not far out in thinking that he regarded all Borneo coal-beds as belonging to one immense Tertiary formation.

There are few countries of the world, except, perhaps, Eastern Australia, where coal is so extensively developed as in Borneo. Thick seams crop out in innumerable places on the coast and on the banks of the rivers. In some of the streams of North Borneo I have seen water- worn and rounded fragments of coal forming the entire shingle bed of the channel. In some places, again, there are outcrops with seams of good coal 26 feet thick. The coal-formation is the one prevailing rock of the coast. It forms the principal outcrop about Sarawak. At Labuan, also, no other rock can be seen. Lining the banks of the Bruni River, I only saw picturesque hills of very old Carboniferous shale. All the grand scenery of the entrance to the port of Gaya is made up of escarpment of coalrocks. At Kirdat it is the same, and so I might go on with a long list of coal-bearing localities.

Now, in such a large island as Borneo, with such a wondrous mountain system, it would be absurd to suppose that all this coal belonged to one age. We might as well suppose the same of the comparatively small islands of Great Britain, and yet what an error that would be. In Eastern Australia and in Tasmania, beds of coal of very different age lie close together. I have found the same in Borneo. Whether there is Tertiary coal or not in the island, I cannot say; but there is Mesozoic coal, and probably Palæozoic coal, and coals like those of Newcastle in Australia, whose position hovers between the true Palæozoic and the Trias. To begin with Labuan: the works there have been long since abandoned; the adits are partly filled with water, and the shafts have fallen in, so that it is next to impossible to explore the mine now. But there is plenty of coal and shale on the surface, and there are excellent sections on the sea-cliffs close by. The formation is a drifted sandstone with much false bedding. It contains not a trace of lime or any marine organism. Under the microscope the siliceous grains are seen to be rounded. I think it is an Eolian formation with lines of rounded pebbles of small size. The whole deposit is very similar to the Hawkesbury sandstone of Australia, which is of Oolitic age. In both formations there are roots and carbonised fragments of coniferous wood, in which the tissue is still to be traced. The coal on the surface is a truly bitumenised coal, very brittle, and like what we get in the same rocks in Australia. The few plant-remains I saw were not referable to any known genus ; they were like Zygophyllites, and perhaps these are the plants which have been identified as wings of Dipterocarpus, which they remotely resemble.

I saw no marine fossil, and the absence of any lime in the beds makes one think that those which were discovered did not come from any of the strata which are exposed in section. Sir Hugh Low, who resided many years at Labuan, gave me some casts of marine fossils taken from the locality. They were casts not easily identified, and certainly not like any now existing of the coast. The molluscan fauna of the locality is that of the usual Indian Oceanic type, with a slight admixture of Chinese and Philippine forms. In all recent bcach remains in these parts of the world there is a large admixture of urchins, corals, \&c. The aspect of the matrix was not of this character. It was much more like a blue-clay such as we have in Australia above the Mesozoic coal.

On the whole, I am inclined to regard the Labuan beds as of Oolitic age, and not Tertiary. Of the value of the coal-seams I had no means of judging. The amount on the surface showed that there was plenty to be had. Labuan is a naval coaling station. Stores of coal are brought out from England at a great expense for the use of her Majesty's navy, and if the same thing could be got in the island the enormous advantages are obvious. I think it should be further tested.

About fifty miles away to the sonth-east is the mouth of the Bruni river. Here the rocks are quite of a different character and much older. They are sandstones, shales, and grits, with ferruginous joints. The beds are inclined at angles of 25 to 45 degrees. They are often altered into a kind of chert. At Moarra there is an outcrop of coalseams 20,25 , and 26 feet thick. The coal is of excellent quality, quite bituminised and not brittle. The beds are 